\title{
Evaluation of a bio-coating as a solution to improve barrier, friction and optical properties of plastic films
}

\begin{tabular}{|r|l|}
\hline Journal: & Packaging Technology and Science \\
\hline Manuscript ID: & PTS-08-0014.R1 \\
\hline Wiley - Manuscript type: & Research Article \\
\hline Author: & 08-Jul-2008 \\
\hline Komplete List of Authors: & $\begin{array}{l}\text { Farris, Stefano; University of Milan, Food Science and Microbiology } \\
\text { Introzzi, Laura; University of Milan, Food Science and Microbiology } \\
\text { Piergiovanni, Luciano; University of Milan, Food Science and } \\
\text { Microbiology }\end{array}$ \\
\hline Keywords: & $\begin{array}{l}\text { barrier properties, bio-coating, gelatin, coefficient of friction, plastic } \\
\text { films }\end{array}$ \\
\hline
\end{tabular}

\section{(5)holarONE" \\ Manuscript Central}




\title{
Evaluation of a bio-coating as a solution to improve barrier, friction
}

\section{and optical properties of plastic films}

\author{
By Stefano Farris*, Laura Introzzi and Luciano Piergiovanni \\ diSTAM, Department of Food Science and Microbiology, University of Milan, Via Celoria 2 - 20133 Milano, Italy
}

\begin{abstract}
The present research dealt with evaluating barrier, friction and optical properties of three different plastic films after deposition of a gelatin-based bio-coating. The composite films showed improved barrier properties against oxygen and UV radiation. The oxygen transmission rate decreased in the order of $73 \%$ for oriented polypropylene (OPP), $56 \%$ for low-density polyethylene (LDPE) and $40 \%$ for polyethylene terephthalate (PET). The increased UV-barrier characteristics ranged from $20 \%$ for OPP to $12 \%$ for both LDPE and PET. Static and kinetic coefficients of friction were significantly decreased both in the film-to-film and in the film-to-metal tests, leading to a desirable value for many applications. However, bio-coated films showed lower optical performances in terms of transparency and haze. Transparency decreased mainly for LDPE (36\%), whereas the haze index increased especially for OPP (85\%). Not significant differences were observed as far as the water vapour permeability is concerned, except for a slight reduction for PET (from $15.78 \mathrm{~cm}^{3} \mathrm{~m}^{-2}$ day $^{-1}$ to $13.53 \mathrm{~cm}^{3} \mathrm{~m}^{-2}$ day $^{-1}$ at $23^{\circ} \mathrm{C}$ and $90 \%$ of $\mathrm{RH}$ ), suggesting that not meaningful effects arose from the addition of a hydrophobic component in the original formulation. Finally, the solubility in water of the coating was around $25 \%$ for all the three plastic substrates. The obtained data suggest that the lipid-protein coating tested in this study, in spite of its great potential for enhancing some characteristics of plastic packaging films, still exhibits negative aspects which necessitate further improvement.
\end{abstract}

KEY WORDS: Barrier properties; bio-coating; gelatin; coefficient of friction; plastic films; UV transmission.

*Correspondence to: S. Farris, Department of Food Science and Microbiology, University of Milan, Via Celoria 2 - 20133 Milano, Italy

Email: stefano.farris@unimi.it 


\section{INTRODUCTION}

Over the last decade, the interest in using natural resources in order to replace, totally or partially, synthetic packaging has increased, as shown by the number of research papers, reviews books and book chapters reported in the scientific literature. ${ }^{1-6}$ Along with the efforts made to preserve high food quality, worldwide attention focused on decreasing plastic waste to improve environmental standing. ${ }^{7}$ The amount of food plastic packaging material is high and one option to replace it is the use of biopolymers, for example in the form of films or coatings. Within bio-based materials, edible films and coatings have received huge attention in the recent years. ${ }^{8-10}$ In fact, films made from polysaccharides, proteins and lipids have shown properties similar to those of plastic films. In addition, they offer some potential advantages represented by the availability, low cost and biodegradability. These characteristics meet the consumers' trends', leading to a greater attention to both what is natural and environmental compatible. Furthermore, for industry, this provides innovative and economic solutions. For these reasons, biopolymers have a potential use as sustainable food packaging materials.

According to these considerations, the application of edible coatings directly on different food items has been deeply investigated by many authors with positive results. ${ }^{11-20}$ Furthermore, it is currently acknowledged by researchers that replacing food plastic packaging using a fully standingalone edible film represents a difficult task to achieve. The major hurdle in this sense is the inability to maintain structural and functional integrity over time, especially due to the high water vapor sensitivity and poor mechanical properties of such structures. ${ }^{7}$ Nevertheless, a first step to use biomacromolecules as food packaging materials could be represented by a combination of both components (plastic and biopolymers), by the deposition of a thin layer on a plastic web. Currently, common plastic films are coated or laminated with synthetic polymers in the form of thin layers in order to increase specific properties of the plastic substrate. For example, polymers like poly vinyl alcohol $(\mathrm{PVOH})$ or ethylene vinyl alcohol $(\mathrm{EVOH})$ are used to achieve high barrier properties against oxygen, whereas polyvinylidene chloride (PVDC) is used both as an excellent water vapour 
and oxygen barrier. Recently, Si-derived coatings seem to offer the best performances in terms of barrier and optical properties. Other meaningful techniques are plasma deposition and metallization. However, each of these surface treatments involves negative aspects, for example costs, technical efforts and environmental impact. For these reasons, the use of biodegradable matrices may represent a valid opportunity in the substitution of the synthetic coatings.

At the present time, very few papers have been published in this field. ${ }^{21-25}$ They have shown that the deposition of thin bio-layers on common plastic films has a great potential. In fact, they could be used for replacing the synthetic polymers utilized in the existing industrial coating processes as well as to reduce the thickness of the plastic substrates attaining the same overall performances. However, in work to date only single biomacromolecular coating formulations (i.e., proteins or polysaccharides) have been investigated. Moreover, authors have focused specifically on the effect of the biopolymeric layers in the enhancement of the oxygen barrier property of the plastic films. To cover the industrial requirements for new solutions, the use of a two- or multi-component coating indeed could represent an alternative path. In this sense, the use of matrices with different characteristics in the coating formulation could improve some performances of the final composite films, for example in terms of barrier, mechanical and optical properties. Thus, to fill the existing gap, this paper examined the use of a lipid-protein matrix as a thin coating on three different plastic films widely used in the food packaging industry. In particular, pigskin gelatin was used as a protein due to its abundance, relatively low cost, filmogenic and foam properties, high barrier properties against oxygen, transparency. ${ }^{26,27}$ This ingredient has been previously used for food applications and also for biomedical purposes to create spheres and capsules for controlled drug delivery. ${ }^{28,29}$ In the present paper, pigskin gelatin was selected to provide the barrier against oxygen and the necessary strength to the biopolymeric layer. An acetylated monoglyceride was chosen as a lipid, in the attempt to provide both best water vapour barrier performances and friction properties of the final composite films. ${ }^{30}$ Moreover, its amphiphilic characteristic should guarantee the adequate interaction with the hydrophilic component, avoiding any kind of phase separation phenomenon 
after deposition. Finally, glycerol was used as a plasticizer to enhance the flexibility of the final structure, preventing coating cracking.

The aim of the present work was to evaluate the effect of a lipid-protein bio-coating on some properties of plastic packaging films. To this purpose, barrier (oxygen and water vapour), friction (static and kinetic coefficients) and optical (haze, transparency and UV transmission) properties of three different plastic films (polypropylene, polyethylene terephthalate and low-density polyethylene) after the coating deposition were evaluated. The possibility to use these kind of layers as a potential and emerging packaging technology was also discussed.

\section{MATERIALS AND METHODS}

\section{Materials}

Pigskin gelatin powder type A, 133 Bloom (Weishardt International, Grauliet Cedex, France) was used as a protein component to make coatings. Acetic acid esters produced from monoglycerides (Grindsted $^{\circledR}$ Acetem 70-00 P) were provided by Danisco (A/S, Langebrogade, Denmark) and were used as lipid component. They are made from edible, fully hydrogenated lard, in which $70 \%$ of the free hydroxyl groups have been acetylated. Finally, glycerol (Giomavaro, Brugherio, Italy) as a plasticizer was added in the coating formulation. Oriented polypropylene (OPP) of $20.0 \pm 0.5 \mu \mathrm{m}$ (Radici Film, S. Giorgio di Nogaro, Italy), polyethylene terephthalate (PET) of $12.5 \pm 0.5 \mu \mathrm{m}$ (Toray Saehan, Kyungbuk, South Korea) and low-density polyethylene (LDPE) of $48.0 \pm 0.5 \mu \mathrm{m}$ (Ticinoplast, Pogliano Milanese, Italy) were used as plastic substrates for the coating deposition. All films were provided by the suppliers as corona-discharge-treated materials.

\section{Preparation of coated films}

Gelatin powder $(11.8 \% \mathrm{w} / \mathrm{w})$ was mixed in distilled water with glycerol $(3.9 \% \mathrm{w} / \mathrm{w})$. The solution was heated to $75^{\circ} \mathrm{C}$, in order to obtain a complete solubilization and denaturation of the protein. The $\mathrm{pH}$ 
was adjusted to the isoelectric point $(\mathrm{pI})$ of the gelatin $(\approx 8.5)$, using sodium hydroxide $(\mathrm{NaOH}) 1$ M. The behaviour of gelatin chains is strongly influenced by the $\mathrm{pH}$ value. In particular, for $\mathrm{pH}$ far from the $\mathrm{pI}$ an electrostatic repulsion exists between gelatin molecules, reducing the number of junction zones connecting different chains. As the $\mathrm{pH}$ approaches the $\mathrm{pI}$, electrostatic repulsion is reduced, due to the net charge along the chain becoming close to 0 . At this specific $\mathrm{pH}$ value the affinity between gelatin and water is little or equal to zero, allowing a high reactivity between the protein and other reactants (e.g. lipids). ${ }^{31}$

The slurry was kept on a mixing heated plate for $1 \mathrm{~h}$. The lipid component $(5.9 \% \mathrm{w} / \mathrm{w})$ was added and mixed for 2 min with a homogenizer (Ika-Werke, Stanfen, Germany), at the speed of $24000 \mathrm{rpm}$. The solution was degassed using a vacuum pump, in order to avoid dissolved air. A constant amount $\left(1.0 \mathrm{~cm}^{3}\right)$ of coating solution was used to coat the corona-treated side $(24 \times 18 \mathrm{~cm})$ of the different plastic films previously placed on an automatic film applicator (Ref. 1137, Sheen Instruments, Kingston, UK) equipped with a steel horizontal bar to obtain a wet coating thickness of $10 \mu \mathrm{m}$. The coating process was performed at a constant speed of $150 \mathrm{~mm} / \mathrm{min}$. Coatings were dried, firstly by using a constant and perpendicular flux of mild air $\left(25 \pm 0.3^{\circ} \mathrm{C}\right)$ at a distance of 40 $\mathrm{cm}$ from the applicator for $2 \mathrm{~min}$. In a second step, composite films were stored under controlled conditions $\left(23 \pm 2{ }^{\circ} \mathrm{C}, 40 \pm 2.0 \% \mathrm{RH}\right)$ for $24 \mathrm{~h}$. Both the neat plastic films and the composite ones (i.e. plastic web and coating) were tested using five independent replicates in regards to thickness, solubility, barrier and optical properties. Coefficients of friction were assessed using ten replicates.

\section{Coating thickness}

The thickness of the uncoated plastic films was measured with a micrometer (Dialmatic DDI030M, Bowers Metrology, Bradford, UK) to the nearest $0.001 \mathrm{~mm}$ at 10 different random locations. For the determination of the thickness of the biodegradable layers coated on the plastic films (Table 1), a $10 \times 10 \mathrm{~cm}$ sample was cut and weighed $\left(M_{1}\right)$. The coating was mechanically removed by hot 
water $\left(80^{\circ} \mathrm{C}\right)$ and the resulting base film weighed $\left(M_{2}\right)$. The thickness of the coating was obtained using the following equation: ${ }^{32}$

$$
l=\frac{M_{1}-M_{2}}{\rho} \times 100
$$

where:

$M_{l}=$ unit total mass (plastic film and coating) $\left(\mathrm{g} \mathrm{dm}^{-2}\right)$

$M_{2}=$ unit mass of the plastic film $\left(\mathrm{g} \mathrm{dm}^{-2}\right)$

$\rho=$ density of the aqueous solution $\left(\mathrm{g} \mathrm{cm}^{-3}\right)$

$l=$ thickness $(\mu \mathrm{m})$

being $M_{1}-M_{2}$ and $\rho$ known. The thickness of the coating was also measured using an optical microscope (OM) (Micro Nikon Eclipse ME600 Laboratory Imaging, Nikon Instruments, Sesto Fiorentino, Italy) at 100x magnification (Figure 1). In this case, films after storage were fixed on a rectangular steel holder and a sharp razor blade was then used in a specific way to cut them, in order to permit the right observation of the cross section of the composite films. Finally, the thickness of the layers was quantified using the software NIS-Element (Nikon Instruments, Sesto Fiorentino, Italy).

\section{Barrier properties}

\section{Oxygen Transmission rate (OTR)}

For the oxygen transmission rate measurement, an OPT-5000 (PBI Dansensor A/S, Ringsted, Denmark) equipped with a zirconia oxygen sensor was used, on the basis of the nearly-isostatic standard method as described by ASTM F 2622-08. ${ }^{33}$ Samples were put in a paperboard support with a testing area of $42 \mathrm{~cm}^{2}$ and then inserted in the instrument. The lower side of the testing area was continually flushed with the carrier gas (nitrogen, $70.0 \mathrm{~cm}^{3} / \mathrm{min}$ flux), whereas the upper side was exposed to the test gas flux (oxygen, $70.0 \mathrm{~cm}^{3} / \mathrm{min}$ ). This leads to a steady-state condition across the sample, so that the oxygen concentration will be the same at any given time. Due to the 
sample's permeability, the lower side (gas with high content of nitrogen) will be enriched with oxygen from the upper side (high concentration of oxygen). Measuring accurately and continuously the increase in oxygen concentration in the lower chamber will determine the permeability. Measurements were performed at a constant temperature $\left(23 \pm 0.5^{\circ} \mathrm{C}\right)$ and at five different relative humidity conditions (from $0 \%$ to $80 \%$ on both sides), in order to determine its influence on the oxygen barrier property of the composite films. A time of $15 \mathrm{~h}$ was allowed for stabilization (i.e. the time needed to the film to reach equilibrium).

\section{Water Vapour Transmission rate (WVTR)}

WVTR was determined by water vapour transmission rate instrument Lyssy L-80 (PBI Dansensor A/S, Ringsted, Denmark). The testing method as described by ASTM E 398-03 Standard Method was used. ${ }^{34}$ Film samples were double masked by manufacturer supplied aluminium foil masks with effective film test area $42 \mathrm{~cm}^{2}$ to prevent the film being damaged during the test. Films were mounted onto instrumental cylinders, followed by analysis. Testing was performed at $23 \pm 0.5^{\circ} \mathrm{C}$, with $100 \% \mathrm{RH}$ for the wet chamber of the instrument and $10 \%$ for the dry one, yielding to a driving force of $90 \%$ RH. Each sample was oriented with the coated side facing the lowest humidity chamber.

\section{Optical properties}

Optical properties were measured using an UV-Vis spectrophotometer (Lambda 650, PerkinElmer, Waltham, USA) for measurements between 200 and $800 \mathrm{~nm}$.

\section{Transparency}

Transparency was determined according to ASTM D $1746-88 .{ }^{35}$ In particular, the transparency of both uncoated and coated films was measured in terms of specular transmittance, i.e. the transmittance value obtained when the transmitted radiant flux includes only the light transmitted in 
the same direction as that of the incident flux in the range 540-560 nm. Then, the correspondent transparency value was obtained by the following equation:

$$
\left(T_{s}\right)=100 I_{s} / I_{0}
$$

where:

$\mathrm{T}_{\mathrm{s}}=$ specular transmittance at $550 \mathrm{~nm}$

$\mathrm{I}_{\mathrm{s}}=$ light intensity with the specimen in the beam

$\mathrm{I}_{0}=$ light intensity with no specimen in the beam

\section{Haze}

Haze was measured in accordance with ASTM D $1003-00 .{ }^{36}$ It is defined as the scattering of light by a specimen responsible for the reduction in contrast of objects viewed through it. In quantitative terms, it is the percent of transmitted light deviating more than an angle of $2.5^{\circ}$ from the direction of the incident beam. For this reason, haze determination necessitates of a proper accessory able to trap also the diffuse transmitted light. To this purpose, a $150 \mathrm{~mm}$ integrating sphere (PerkinElmer, Waltham, USA) was used, where the transmittance sample holder at the entrance of the sphere enables the measurement of light scattering films. In this way it is avoided any loss of light before it reaches the detector, because all the light which has passed through the sample is collected.

\section{UV transmission properties}

UV transmission properties were evaluated by collecting transmittance spectra of neat and coated plastic films in the UV region $200-340 \mathrm{~nm}$. The area under each transmittance curve was calculated by an integration process. The smaller the area value, the greater will be the UV barrier properties for the specific film taken into account. UV transmission properties too were estimated using a 150 $\mathrm{mm}$ integrating sphere.

\section{Friction properties}


In this work, both static $\left(\mu_{s}\right)$ and kinetic $\left(\mu_{k}\right)$ friction coefficients were measured. The former represents the friction opposing the onset on relative motion (impending motion), whereas the latter can be considered as the friction opposing the continuance of relative motion once that motion has started. $^{37}$ In the case of solid-on-solid friction (with or without lubricants), these two types of friction coefficients are conventionally defined as follows:

$$
\begin{aligned}
& \mu_{s}=F_{s} / P \\
& \mu_{k}=F_{k} / P
\end{aligned}
$$

where:

$F_{\mathrm{s}}=$ force just sufficient to prevent the relative motion between two bodies;

$F_{\mathrm{k}}=$ force needed to maintain relative motion between two bodies;

$P=$ force normal to the interface between the sliding bodies.

Both friction coefficients were measured using a dynamometer (mod. Z005, Zwick Roell, Ulm, Germany), in accordance with the standard method ASTM D 1894-87. ${ }^{38}$ The software 'TestXpert V10.11 Master' was used for data analysis. Two types of analyses were carried out. In the first, friction opposing the motion of each type of film (coated and uncoated) against itself was evaluated. In the second, the motion of each type of film (coated and uncoated) on a metallic rigid surface (a polished stainless steel 150 by 450 by $3 \mathrm{~mm}$ ) was considered. This surface, other than acting as a supporting base to guarantee a firm position between the moving crosshead and the force-measuring device, served the purpose of simulating the friction between the plastic web and the metallic parts of the equipments used during the manufacturing process.

\section{Coating solubility (total soluble matter)}

According to Gontard et al., ${ }^{39}$ film solubility in water was measured as a percentage of dry matter of the bio-coating solubilized after $24 \mathrm{~h}$, assuming that the plastic substrate does not dissolve at the 
same conditions. Composite films (plastic and coating) were kept in a desiccator containing calcium chloride for $24 \mathrm{~h}$. These films were cut by $10 \times 10 \mathrm{~cm}$, weighed, immersed in $250 \mathrm{~cm}^{3}$ distilled water, sealed, and periodically agitated for $24 \mathrm{~h}$ at $20^{\circ} \mathrm{C}$ in an incubator (MCT 120, Angelantoni Scientifica, Massa Martana, Italy). After this time, the same film pieces were taken out and dried at $100^{\circ} \mathrm{C}$ for $24 \mathrm{~h}$ to determine the weight of dry matter. Solubility was then calculated as follows:

$$
\text { Solubility }(\%)=\left[\left(d m_{i}-d m_{f}\right) / d m_{i}\right] \times 100
$$

where:

$d m_{i}=$ initial dry matter of the composite films

$d m_{f}=$ dry matter of the composite films after $24 \mathrm{~h}$ immersion in water

\section{Statistical analysis}

Statgraphics Plus 4.0 software (STSC, Rockville, USA) was used for the one-way ANOVA, in order to check for differences between and within groups (each plastic film, coated and uncoated). The mean values, when appropriate, were separated by LSD's multiple range test at $p \leq 0.05$.

\section{RESULTS AND DISCUSSION}

\section{Barrier properties}

\section{Oxygen Transmission rate (OTR)}

Table 1 shows the results obtained for the oxygen transmission rate for uncoated and coated plastic films at $0 \%$ relative humidity. As can be seen, the addition of the biopolymeric layer led to a drastic decrease of the oxygen permeability, ranging from $73 \%$ for the OPP to $40 \%$ for the PET. The barrier effect of the coating is undoubtedly due to the presence of gelatin. This protein exhibits oxygen permeability roughly close to that of PVDC and EVOH films at $0 \%$ relative humidity. ${ }^{40,41}$ 
Moreover, its high linear structure makes it a grater oxygen-barrier than others globular proteins (corn zein, wheat gluten, soy protein or whey protein) due to a higher cohesive energy density and a lower free volume. ${ }^{42}$ However, in this work the extent of the improvement of the oxygen barrier property of the three plastic films due to the addition of the coating was lower if compared to the results achieved in similar studies. ${ }^{21,22,25}$ This is linked to the different thickness of the plastic film and of the coating. In fact, previous research used plastic films of around $50.0 \mu \mathrm{m}$ thickness, whereas the coating as used in this work had a thickness not less than $6.0 \mu \mathrm{m}$, hence three times greater than the gelatin-based coating tested in the present study. In addition, the initial coating formulation has to be kept in mind. In contrast to previous works, a lipid component is also present in the gelatin-based coating designed for this research. Although the addition of hydrophobic molecules is view as necessary to improve the water vapour barrier property of films, its presence causes a decrease in the cohesive energy density of the protein network and a consequent increase in free volume, acting as a plasticizer. ${ }^{30}$ The final result is a less tight lattice (i.e. increased interstitial space between protein molecules) and a reduced energy binding together the protein chains, thus allowing a permeant (oxygen) to pass faster across the sample. In Figures 2-4 the evolution of the oxygen transmission rate as a function of the relative humidity is reported, for both uncoated and coated films. It is interesting to observe as the uncoated OPP and LDPE barrier properties against oxygen were almost constant over the whole investigated RH range. Conversely, the OTR values of uncoated PET decreased when increasing RH. This behavior, though unusual, is typical for those polymers like PET and aromatic polyamides, and it seems due to decreases in both diffusivity $(D)$ and solubility $(S)$ of the permeant as a consequence of water molecules absorption by the film. ${ }^{43}$ With regard to the coated films, there is a great dependence of the OTR values on relative humidity. In particular, values similar to those measured at anhydrous conditions were measured up to $40 \%$ RH for OPP $\left(640 \pm 15 \mathrm{~cm}^{3} \mathrm{~m}^{-2}\right.$ day $\left.{ }^{-1}\right)$, PET $\left(75 \pm 5.8 \mathrm{~cm}^{3} \mathrm{~m}^{-2} \mathrm{day}^{-1}\right)$ and PE $\left(1400 \pm 15 \mathrm{~cm}^{3} \mathrm{~m}^{-2}\right.$ day $\left.^{-1}\right)$. Beyond this RH limit-value the increase was significant and followed an exponential trend, in agreement with previous works. ${ }^{21,22,25}$ Such behaviour is analogous to that of 
commercial synthetic polymers often used in coating or lamination process such as poly vinyl alcohol $(\mathrm{PVOH})$ or ethylene vinyl alcohol $(\mathrm{EVOH})$. The high moisture-sensitivity limits their application to food items with low water activity, unless these polymers are incorporated as inner layers between polyolefins or other polymers acting as barriers against water vapour. The pronounced hydrophilic nature of gelatin is by far the main factor leading to the different behaviour of the films when altering the relative humidity of the system. It could be ascribed to the chemical structure of gelatin, i.e. the amino acid composition. In fact, pigskin gelatin is composed of approximately $45 \%$ hydrophillic amino acids like glycine, glutamic acid, serine. ${ }^{44}$ Accordingly, gelatin interacts easily with the surroundings, absorbing water from the environmental humid air and therefore undergoing significant physical changes. In particular, the gelatin-water interaction leads both to an increased mobility in the hydrophilic macromolecule chains and to the swelling of the protein network, which are at the base of the gas diffusivity and gas solubility phenomena, respectively. ${ }^{45}$ In spite of its small thickness, the bio-coating laid on OPP, PET and LDPE effectively reduced their OTR, even though only at low to intermediate RH. These results are of great interest, due to the possibility to improve the oxygen barrier performances of the plastic films using very thin biopolymeric layers. Moreover, the performance of the biodegradable films themselves can be properly improved by different approaches, like the modification of the original formulation, the use of different deposition process or promoting physical-chemical changes by using, for example, specific cross-linking agents.

\section{Water Vapour Transmission rate (WVTR)}

To accomplish the enhancement of the water vapour (WV) barrier property of the plastic films, a lipid component (acetylated monoglyceride) was added to the glycerol/protein matrix with a ratio lipid/protein $=0.5$. The obtained results are displayed in Table 1 . Only a small effect on the WVTR of the PET-coated film was measured $(\approx 15 \%$ decrease), whereas the presence of the bio-coating did not lead to any significant changes in the WV barrier characteristics of OPP and LDPE films. It 
could be explained considering that, at $\mathrm{T}=23^{\circ} \mathrm{C}$, OPP and LDPE themselves are excellent water vapour barriers, and the addition of a coating with a low fat-to-protein ratio is not enough to affect their initial performances. The same coating laid down on the PET film, instead, had some positive effect, even if of limited size. This is because of the different nature of PET, less hydrophobic than OPP and LDPE and hence with a higher initial WVTR value. According to Anker et al., ${ }^{30}$ these results establish that composite films and coatings made by the emulsion technique (in which the lipid component is dispersed through the predominant network, gelatin in this case) exhibit rather poor barrier properties against water vapour, due to the fact that water molecules are still able to permeate through the hydrophilic phase (i.e. gelatin). One solution could be to move from a low fatto-protein ratio to a high fat-to-protein ratio, in order to increase the hydrophobic nature of the coating. However, Anker et al. ${ }^{30}$ also demonstrated that by increasing the lipid/protein ratio the WV barrier properties did not change. Therefore, further studies are necessary to elucidate the proper use of the lipid component in order to decrease significantly WVTR of the most important commercial films. To this purpose, changes in the experimental conditions and in the mechanism of addition of the lipid component to the protein matrix (e.g. lamination) might lead to better results.

\section{Optical properties}

The optical properties of plastic films for food packaging applications are of great importance not only as far as the quality preservation of the foods is concerned, but also from an aesthetic and hedonistic point of view. From one hand, for instance, it should be desirable to have films with high barrier performances against the UV radiation, in order to avoid damaging reactions (e.g. lipid oxidation, discolouration). On the other hand, industries are always looking towards new solutions dealing with transparent films, due to the increasing consumers demand to 'see through' the package. At the same time, by using transparent films, companies can also compete against each other on the basis of the appearance of the product. Due to that, the present research also dealt with the influence of a bio-coating on some optical characteristics of three common plastic films. In 
particular, this study examined whether the overall effect could be considered positive, in order to plan future improvements on the original coating formulation.

\section{Transparency and Haze}

Transparency is the property of a material that allows seeing through it. Transparency of the coated films was inferior to that of the neat films. As shown in Table 1, the transparency values (\%) decreased $17 \%$ for OPP $(90.46-75.04), 12 \%$ for PET $(82.27-72.69)$ and $36 \%$ for LDPE $(84.10-$ 54.05). On the contrary, haze is the property of a material of scattering the incident light. It is linked to the reduction in contrast of objects viewed through it. The deposition of the coating led to a consistent increase in haze for all the three plastic films. In particular, the haze index increased mainly for OPP (85.5\%) followed by LDPE (78\%) and PET (70\%). The decrease in transparency of the plastic films after coating deposition is undoubtedly attributable to the lipid component. In this sense, it is worth noting the increased turbidity of the protein-based slurry after lipid incorporation. According to Rhim et al., ${ }^{46}$ an increase in haze (and a consequent decrease in transparency) occurs in edible films upon the addition of fatty acids (e.g. lauric, palmitic, stearic, oleic). Kim and $\mathrm{Ustunol}^{47}$ reported that a trained sensory panel perceived whey protein isolate films as significantly less transparent after the addition of the fat component (candelilla wax, in this case). As highlighted by Hernandez, ${ }^{48}$ transparency and haze of both plastic and biodegradable films is primarily related to their morphology and not to their chemical structure. The obtained results are due not only to the irregularities at the surface level, but also to the morphological inhomogeneity of the coating thickness across the width. In particular, the lipid component in the final formulation is in the form of tiny drops entrapped in the gelatin network, especially after mechanical homogenization. These particles promoted the scattering phenomenon of visible light through the film, hence causing an increase in the haze values. From the experimental results it can be concluded that the coating designed according to the proposed formulation is hardly suitable for those packaging applications in which the transparency of the polymer is a required prerequisite to assure product visibility. 
Conversely, their practical application could involve all those packaging solutions not requiring high transparency values. In any case, improvements may include the process optimization (e.g. homogenization, amount, thickness), in order to enhance these optical properties.

\section{UV transmission properties}

The negative effect of light on foods (especially dairy and meat products) has been extensively investigated by different researchers, as reviewed by Mortensen et al. ${ }^{49}$ Foods exposed to light (natural or artificial) may undergo a severe quality decay, often due to light-induced degradation of macromolecules like proteins, lipids and also vitamins. The role of the UV light is not negligible because even small amounts of this radiation can promote the formation of free radicals from lipids leading to photolytic autoxidation. Moreover, UV light seems to have a detrimental effect on vitamins and pigment degradation. ${ }^{50,51}$ The final result is the appearance of off-flavours and significant changes in colour that preclude their marketing. Among the different approaches that could prevent these changes (food formulation and processing, storage and light exposure conditions), the choice of an ideal packaging appears fundamental. The problem could be easily solved using metallized plastic films or aluminium foils acting as a total barrier; however, they do not enable the consumers to see the quality of the foods through the package. For that reason, the use of transparent material is increasing, even with risking degradation of foods packaged in this kind of films. In recent years, besides the practice of modifying the composition of the internal atmosphere of a package (i.e. reducing the amount of oxygen), the use of UV filters paved the way for new interesting solutions. In light of all these considerations, in the present study the transmission spectra of both composite and neat films were collected within the wavelength region 380-200 nm. The area under each transmittance curve was then collected, in order to check for some differences in the UV transmission properties after the coating application. As reported in Figure 5, the bio-coating led to an enhancement of the UV transmission properties for the OPP and LDPE films. The major component involved in this 'blocking-UV' capacity is the protein, as widely 
explained by Schaich. ${ }^{52}$ In particular, this UV-absorbing behaviour has to be attributed to the aromatic amino acids in the gelatin composition, like phenylalanine and tyrosine. In addition, further evidence was given by comparing the spectra obtained from films coated in accordance to the original formulation with those obtained from films coated in absence of the lipid component. As displayed by the Figure 6, the transmittance spectra of OPP coated in the absence of the acetylated monoglyceride are downwards-shifted with respect to those obtained with the lipid component in the formulation, confirming that gelatin is able to partially block the UV radiation, whereas the lipid drops dispersed in the coating reduce this effect. To corroborate this hypothesis it must be highlighted that the stearic acid in the monoglyceride is saturated, and hence it has no double bonds which would normally absorb the UV-light. Although the UV barrier properties of the three plastic films increased after coating deposition, it is important to stress that they have a moderate impact from a practical point of view. This is due to the fact that the most UV-induced degradation phenomena during food storage at manufacturing facilities and in retails stores arise from artificial sources generating especially UV-a and UV-b radiation, ranging approximately between 380 and $280 \mathrm{~nm}$. The biodegradable coating increased significantly the UV barrier properties of OPP and LDPE plastic films only for the spectral region below $240 \mathrm{~nm}$ (Figure 5), i.e. the UV-c region including high-energy light (e.g. sunlight) emitted in a negligible amount from halogen and fluorescent lamps used in the markets. ${ }^{48}$ In contrast, the UV-blocking effect of the coating without the lipid component started from $300 \mathrm{~nm}$ even if the greatest effect was encountered starting from $250 \mathrm{~nm}$. Also in this case, some further changes could be made to improve this property, for example by selecting a different natural compound able to absorb the UV radiation in the targeted range.

\section{Friction properties}

The influence of the coating deposition on the overall mechanical properties of plastic films is strictly related to the specific test performed. Accordingly, as reported in previous work, ${ }^{24}$ if the 
tensile properties are examined (e. g. tensile strength, elongation at break, elastic modulus), the final results tend to have a great dependence on the substrate rather than the layer applied on it. Just the opposite occurs when surface properties such as the static and kinetic friction coefficients are measured. Different films (above all polyolefin) tend to adhere to them or to the production equipment during film processing, causing severe trouble in terms of slowdown in performance and productivity. In order to simulate the practical situation often occurring at industrial level, two different analyses of the same test were performed in this work: the sliding of parallel film surfaces over each other and the sliding of film surfaces over a metal substrate. Great differences may be observed after deposition of the thin coating on the plastic substrates (Figure 7). This is basically due to the specific friction characteristics of the coating, which are independent from its thickness and which could be affected by the type of substrate on which is spread on (e.g. the substrate's own smoothness) and by the coating uniformity, as shown by the results reported in Table 1 . The overall positive effect arising from the deposition of the coating on plastic films is attributable to the lipid component, which acts as a true slip agent. In confirmation, stearic acid is often used in the amidation process to obtain primary amides (i.e. stearamide) as well as the oleic acid (C18:1) and the erucic acid (C22:1) are used to obtain oleamide and erucamide, the most popular slip agents used during extrusion processes of polyolefin. ${ }^{53-55}$ The obtained results appear interesting from a practical point of view, especially considering the potential industrial application. Using such coatings including a lipid component as a slip agent allows a layer of film to slide easily over another layer of film (e.g. on a roll), or over machine surfaces during film manufacture and packing, reducing the coefficient of friction $(\mathrm{CoF})$. Therefore, the final result will be the increased line speed in the manufacturing process and the enhancement of the packaging machine operations, resulting in an increased output.

\section{Coating solubility (total soluble matter)}


Solubility in water of coatings prepared from biomacromolecules is an important property strictly influencing its practical application. Some potential applications might require a very low water sensitivity, in order to maintain over time the initial benefits (mainly physical properties) arising from the coating application. For some other applications (e.g. medical, nutritional), these layers may be intended as a controlled release packaging system, for example for delivering active components (e.g. antimicrobials, antioxidants) in a controlled manner over time. In other cases a total solubility of the film appears beneficial before product consumption, for example when nutraceuticals have been incorporated in foods such as yoghurt. ${ }^{56}$ Consequently, the study of the coating solubility in water represents a preliminary step to understand its possible applications and, eventually, to design new solutions. As reported in Table 1, the three different composite films showed similar solubility values (around 25\%). At least three different factors contribute to this result. Firstly, the high hygroscopic nature of the protein and glycerol, able to interact with water molecules that penetrate in the bio-polymer bulk promoting at the beginning its swelling and then its dissolution, due to the wrecking of the hydrogen and Van der Waals forces between polymer chains. Secondly, this process could be accelerated by the presence of the lipid component entrapped in the protein matrix. As explained above, the lipid component acts as a plasticizer, reducing the cohesive energy between protein chains and increasing the interstitial space between protein molecules allowing water to penetrate faster. Finally, an opposite force limits the coating dissolution, i.e. the strong bond between the biodegradable matrix and the substrate. In this case it is important to point out the positive effect arising from the corona discharge treatment, a routinely industrial practice able to impart good adhesion between two different polymers (plastic film and bio-coating, in this case) and a better strength to the final composite structures as well. The partial dissolution of the bio-layer suggests that the formulation assumed for this research could be used for short shelf-life food applications or when the controlled release of active compounds (e.g. antimicrobials, antioxidant substances) is required. In this sense, a further work is in progress in order to relate the coating behaviour in contact to a medium different than water as well as to 
investigate which components of the original formulation are more susceptible to dissolve. Moreover, changes in solubility can be achieved by chemical-physical modifications of the coating (e.g. using cross-linking agents).

\section{Conclusions}

It is possible to modify the original properties of common synthetic films by means of thin biocoatings deposition. However, using two different components such as protein and lipid in the same formulation does not seem at the moment the best way to promote the improvement of some important performances of plastic substrates. This is because the addition of a lipid component in the original formulation did not lead to any meaningful and significant improvement of the original characteristics, with the exception of the friction properties. The addition of the monoglyceride acetylated to the gelatin-based formulation indeed reduced some positive effects provided by the protein biopolymer, such as the optical properties (in terms of haze and transparency), the UVabsorbing capacities and likely the oxygen barrier property too. Although these negative effects, such composite layers may represent a potential way able to meet the increasing demand for more sustainable solutions, especially if some aspects will be improved on. For example, the possibility to apply macromolecules with opposite characteristics by a lamination process should be carefully investigated. In addition, to accomplish the industrial demand for low-cost and high-performance new solutions, the enhancement of the formulation is needed, starting from the systematic study of the influence of the most important factors (e.g. components and process conditions) on the final properties of the coatings. Subsequently, an optimization step can be carried out by the modification of the chemical and physical structure of the polymer according to the required performances. Finally, further investigations should be done concerning some potential aspects, like the possibility to incorporate in these coatings active compounds for controlled release purposes and their sealing properties. 
The huge potential involved in this ongoing innovation appears obvious. Their application on plastic films may allow the reduction of oil-derived polymers both replacing the already-existing synthetic coatings and reducing the thickness of the plastic web on which they should be spread on. In addition, considering the low unit price of the raw materials as well as the possibility to use the already existing coating equipments at industrial level, a significant reduction of the cost of the manufacturing process is also expected. 


\section{References}

1. Petersen K, Vaeggemose Nielsen P, Bertelsen G, Lawther M, Olsen MB, Nilsson NH, Mortensen G. Potential of biobased materials for food packaging. Trends Food Sci. Technol. 1999; 10: 52-68. DOI: 10.1016/S0924-2244(99)00019-9.

2. Webery CJ, Hugaard V, Festersen R, Bertelsen G . Production and applications of biobased packaging materials for the food industry. Food Addit. Contam. 2002; 19: 172-177. DOI: $10.1080 / 02652030110087483$.

3. Plackett DV, Holm VK, Johansen P, Ndoni S, Vaeggemose Nielsen P, Sipilainen-Malm T, Sodergard A, Verstichel S. Characterization of L-polylactide and L-polylactidepolycaprolactone co-polymer films in use in cheese-packaging applications. Packag. Technol. Sci. 2006; 19: 1-24. DOI: 10.1002/pts.704.

4. Krochta JM, De Mulder-Johnston C. Edible and biodegradable polymer films: challenges and opportunities. Food Technol. 1997; 51: 61-74.

5. Weber CJ. Biobased Packaging Materials for the Food Industry - Status and perspectives. Report of the combined effort of the project partners of the Food Biopack Project funded by the EU Directorate 12, November 2000.

6. Han JH. Innovations in Food Packaging. Elsevier Academic Press: New York, 2005.

7. Tharanathan RN. Biodegradable films and composite coatings: past, present and future. Trends Food Sci. Technol. 2003; 14, 71-78. DOI: 10.1016/S0924-2244(02)00280-7.

8. Debeaufort F, Quezada-Gallo JA, Voilley A. Edible films and coatings: tomorrow's packagings: a review. Crit. Rev. Food Sci. 1998; 38: 299-313.

9. Guilbert S, Gontard N, Gorris LGM. Prolongation of the shelf-life of perishable food products using biodegradable films and coatings. Lebensm.-Wiss. Technol. 1996; 29, 10-17. DOI: $10.1006 /$ fstl.1996.0002.

10. Krochta JM, Baldwin EA, Nisperos-Carriedo M. Edible Coatings and Films to Improve Food Quality. Technomic: Lancaster, PA, 1994. 
11. Jagannath JH, Nanjappa C, Das Gupta D, Bawa AS. Studies on the stability of an edible film and its use for the preservation of carrot (Daucus carota). Int. J. Food Sci. Tech. 2006; 41: 498-506. DOI: 10.1111/j.1365-2621.2005.01038.

12. Del-Valle V, Hernandez-Munoz P, Guarda A, Galotto MJ. Development of a cactusmucilage edible coating (Opuntia ficus indica) and its application to extend strawberry (Fragaria ananassa) shelf-life. Food Chem. 2005; 91: 751-756. DOI: 10.1016/j.foodchem.2004.07.002.

13. Maftoonazad N, Ramaswamy HS, Moalemiyan M, Kushalappa AC. Effect of pectin-based edible emulsion coating on changes in quality of avocado exposed to Lasiodiplodia theobromae infection. Carbohyd Polym. 2007; 68: 341-349. DOI: 10.1016/j.carbpol.2006.11.020.

14. Chien PJ, Sheu F, Yang FH. Effects of edible chitosan coating on quality and shelf life of sliced mango fruit. J. Food Eng. 2007; 78: 225-229. DOI: 10.1016/j.jfoodeng.2005.09.022.

15. Durango AM, Soares NFF, Andrade NJ. Microbiological evaluation of an edible antimicrobial coating on minimally processed carrots. Food Control 2006; 17: 336-341. DOI: 10.1016/j.foodcont.2004.10.024.

16. Khalil AH. Quality of french fried potatoes as influenced by coating with hydrocolloids. Food Chem. 1999; 66: 201-208. DOI: 10.1016/S0308-8146(99)00045.

17. Tanada-Palmu PS, Grosso CRF. Effect of edible wheat gluten-based films and coatings on refrigerated strawberry (Fragaria ananassa) quality. Postharvest Biol. Tec. 2005; 36: 199208. DOI: $10.1016 /$ j.postharvbio.2004.12.003.

18. Bravin B, Peressini D, Sensidoni A. Development and application of polysaccharide-lipid edible coating to extend shelf-life of dry bakery products. J. Food Eng. 2006; 76: 280-290. DOI: 10.1016/j.jfoodeng.2005.05.021.

19. Xu S, Chen X, Sun DW. Preservation of kiwifruit coated with an edible film at ambient temperature. J. Food Eng. 2001; 50: 211-216. DOI: 10.1016/S0260-8774(01)00022. 
20. Kang HJ, Jo C, Kwon JH, Kim JH, Chung HJ, Byun MW. Effect of a pectin-based edible coating containing green tea powder on the quality of irradiated pork patty. Food Control 2007; 18: 430-435. DOI: 10.1016/j.foodcont.2005.11.010.

21. Hong SI, Krochta JM. Oxygen barrier properties of whey protein isolate coatings on polypropylene films. J. Food Sci. 2003; 68: 224-228. DOI: 10.1111/j.13652621.2003.tb14143.

22. Hong SI, Krochta JM. Whey protein isolate coating on LDPE film as a novel oxygen barrier in the composite structure. Packag. Technol. Sci. 2004; 17: 13-21. DOI: 10.1002/pts.634.

23. Hong SI, Han JH, Krochta JM. Optical and surface properties of whey protein isolate coatings on plastic films as influenced by substrate, protein concentration, and plasticizer type. J. Appl. Polym. Sci. 2004; 92: 335-343. DOI: 10.1002/app.20007.

24. Hong SI, Lee JW, Krochta JM. Properties of polysaccharide-coated polypropylene films as affected by biopolymer and plasticizer types. Packag. Technol. Sci. 2005; 18: 1-9. DOI: $10.1002 /$ pts. 667 .

25. Hong SI, Krochta JM. Oxygen barrier performance of whey-protein-coated plastic films as affected by temperature, relative humidity, base film and protein type. J. Food Eng. 2006; 77: 739-745. DOI: 10.1016/j.jfoodeng.2005.07.034.

26. Gennadios A, McHugh TH, Weller CL, Krochta JM. Edible coatings and films based on proteins. In Edible coatings and films to improve food quality, Krochta JM, Baldwin EA, Nisperos-Carriedo M (eds.). Lancaster:Technomic, 1994; 210-278.

27. Arvanitoyannis IS. Formation and properties of collagen and gelatin films and coatings. In Protein-based films and coatings, Gennadios A (ed.). Boca Raton: CRC Press, 2002; 275304.

28. Mwangi JW, Ofner CM. Crosslinked gelatin matrices: release of a random coil macromolecular solute. Int. J. Pharm. 2004; 278: 319-327. DOI: 10.1016/j.ijpharm.2004.03.024. 
29. Dong Z, Wang Q, Du Y. Alginate/gelatin blend films and their properties for drug controlled release. J. Membrane Sci. 2006. 280: 37-44. DOI: 10.1016/j.memsci.2006.01.002.

30. Anker M, Berntsen J, Hermansson AM, Stading M. Improved water vapour barrier of whey protein films by addition of an acetylated monoglyceride. Innov. Food Sci. Emerg. 2002; 3: 81-92. DOI: 10.1016/S1466-8564(01)00051-0.

31. Djagny KB, Wang Z, Xu S. Chemical modification of pigskin gelatin: factors affecting the esterification of gelatin with fatty acid. J. Food Sci. 2001; 66: 1326-1330. DOI: 10.1111/j.1365-2621.2001.tb15209.

32. Brown WE. Plastics in Food Packaging - Properties, Design and Fabrication. Dekker: New York, 1992; 200-202.

33. ASTM. Standard test method for oxygen gas transmission rate through plastic film and sheeting using various sensors. Designation F 2622-08. American Society for Testing and Materials.

34. ASTM. Standard test method for water vapour transmission rate of sheet materials using dynamic relative humidity measurement. Designation E 398 - 03. American Society for Testing and Materials.

35. ASTM. Standard test method for transparency of plastic sheeting. Designation D $1746-88$. American Society for Testing and Materials.

36. ASTM. Standard test method for haze and luminous transmittance of transparent plastics. Designation D 1003 - 00. American Society for Testing and Materials.

37. Blau PJ. The significance and use of the friction coefficient. Tribol. Int. 2001; 34: 585-591. DOI: $10.1016 / \mathrm{S} 0301-679 \mathrm{X}(01) 00050-0$.

38. ASTM. Standard test method for static and kinetic coefficients of friction of plastic film and sheeting. Designation D 1894 - 87. American Society for Testing and Materials. 
39. Gontard N, Guilbert S, Cuq JL. Edible wheat gluten films: influence of the main process variables on film properties using response surface methodology. J. Food Sci. 1992; 57: 190-195, 199. DOI: 10.1111/j.1365-2621.1992.tb05453.

40. Salame M. Barrier polymers. In The Wiley Encyclopedia of packaging technology $\left(1^{\text {st }} \mathrm{ed}\right)$, Bakker M (ed.). John Wiley and Sons Inc.: New York, 1986; 51-52.

41. Brown WE. Vinyldene chloride copolymers. In The Wiley Encyclopedia of packaging technology $\left(1^{\text {st }}\right.$ ed), Bakker M (ed.). John Wiley and Sons Inc.: New York, 1986; 694.

42. Miller KS, Krochta JM. Oxygen and aroma barrier properties of edible films: a review. Trends Food Sci. Technol. 1997; 8: 228-237. DOI: 10.1016/S0924-2244(97)01051-0.

43. Hu YS, Mehta S, Schiraldi DA, Hiltner A, Baer E. Effect of water sorption on oxygenbarrier properties of aromatic polyamides. J. Polym. Sci. Pol. Phys. 2005; 43: 1365-1381. DOI: $10.1002 /$ polb.20425.

44. Sobral PJA, Menegalli FC, Hubinger MD, Roques MA. Mechanical, water vapour barrier and thermal properties of gelatin based edible films. Food Hydrocolloid 2001; 15: 423-432. DOI: $10.1016 / \mathrm{S} 0268-005 \mathrm{X}(01) 00061-3$.

45. Guilbert S, Gontard N. Agro-polymers for edible and biodegradable films: review of agricultural polymeric materials, physical and mechanical characteristics. In Innovations in food packaging, Han JH (ed.). Elsevier Academic Press: New York, 2005; 263-274.

46. Rhim JW, Wu Y, Weller CL, Schnepf M. Physical characteristics of emulsified soy proteinfatty acid composite films. Sci. Aliment. 1999; 19: 57-71.

47. Kim SJ, Ustunol Z. Sensory attributes of whey protein isolate and candelilla wax emulsion edible films. J. Food Sci. 2001; 66: 909-911. DOI: 10.1111/j.1365-2621.2001.tb15195.

48. Hernandez R. Polymer properties. In The Wiley Encyclopedia of packaging technology $\left(^{\text {nd }}\right.$ ed), Brody AL, Marsh KS (eds.). John Wiley and Sons Inc.: New York, 1997; 758-765. 
49. Mortensen G, Bertelsen G, Mortensen BK, Stapelfeldt H. Light-induced changes in packaged cheeses - a review. Int. Dairy J. 2004; 14: 85-102. DOI: 10.1016/S09586946(03)00169-9.

50. Cladman W, Scheffer S, Goodrich N, Griffiths MW. Shelf-life of milk packaged in plastic containers with and without treatment to reduce light transmission. Int. Dairy J. 1998; 8: 629-636. DOI: 10.1016/S0958-6946(98)00094-6.

51. Limbo S, Torri L, Piergiovanni L. Light-induced changes in an aqueous $\beta$-carotene system stored under halogen and fluorescent lamps, affected by two oxygen partial pressures. $J$. Agr. Food Chem. 2007; 55: 5238-5245. DOI: 10.1021/jf0634348.

52. Schaich KM. Free radical initiation in proteins and amino acids by ionizing and ultraviolet radiations and lipid oxidation - Part II: Ultraviolet radiation and photolysis. Crit. Rev. Food Sci. 1980; 13: 131-159.

53. Piringer OG, Baner AL. Plastic Packaging Materials for Food. Wiley: Weinheim, 2000; 4748.

54. Peloso CW, O'Connor MJ, Bigger SW, Scheirs J. Characterising the degradation of the polymer slip additive erucamide in the presence of inorganic antiblock agents. Polym. Degrad. Stabil. 1998; 62: 285-290. DOI: 10.1016/S0141-3910(98)00009-3.

55. Garrido-Lòpez A, Esquiu V, Tena MT. Comparison of three gas chromatography methods for the determination of slip agents in polyethylene films. J. Chromatogr. A 2007; 1150: 178-182. DOI: 10.1016/j.chroma.2006.11.090.

56. Pérez-Gago MB, Nadaud P, Krochta JM. Water vapour permeability, solubility, and tensile properties of heat-denaturated versus native whey protein films. J. Food Sci. 1999; 64: 1034-1037.DOI: 10.1111/j.1365-2621.2002.tb11387. 


\section{Table}

\begin{tabular}{|c|c|c|c|c|c|c|c|c|c|c|c|}
\hline \multirow{4}{*}{ Film } & \multicolumn{11}{|c|}{$\begin{array}{l}\text { Table 1. Thickness, Oxygen Transmission Rate }(O T R) \text {, Water Vapour Transmission Rate (WVTR), Haze, } \\
\text { Transparency, Coefficient of Friction and Solubility of coated and uncoated plastic films }\end{array}$} \\
\hline & & \multirow{3}{*}{$\begin{array}{l}\text { Thickness } \\
(\mu \mathrm{m})\end{array}$} & \multirow{3}{*}{$\begin{array}{l}\mathrm{OTR}^{\mathrm{a}} \\
\left(\mathrm{cm}^{3} \mathrm{~m}^{-2} \mathrm{day}^{-1}\right)\end{array}$} & \multirow{3}{*}{$\begin{array}{l}\text { WVTR } \\
\left(\mathrm{g} \mathrm{m}^{-2} \mathrm{day}^{-1}\right)\end{array}$} & \multirow{3}{*}{$\begin{array}{l}\text { Haze } \\
(\%)\end{array}$} & \multirow{3}{*}{$\begin{array}{l}\text { Transparency } \\
(\% \mathrm{~T})\end{array}$} & \multicolumn{4}{|c|}{ Coefficient of Friction (CoF) } & \multirow{3}{*}{$\begin{array}{l}\text { Solubility of the } \\
\text { bio-layer (\%) }\end{array}$} \\
\hline & & & & & & & \multicolumn{2}{|c|}{ Film-to-film } & \multicolumn{2}{|c|}{ Film-to-metal } & \\
\hline & & & & & & & $\mu_{\mathrm{k}}$ & $\mu_{\mathrm{s}}$ & $\mu_{\mathrm{k}}$ & $\mu_{\mathrm{s}}$ & \\
\hline \multirow[t]{2}{*}{ OPP } & Uncoated & $\begin{array}{l}19.6 \\
( \pm 1.41)\end{array}$ & $\begin{array}{l}1715.67 \\
( \pm 17.10)\end{array}$ & $\begin{array}{l}1.09 \\
( \pm 0.11)^{*}\end{array}$ & $\begin{array}{l}1.60 \\
( \pm 0.04)\end{array}$ & $\begin{array}{l}90.46 \\
( \pm 0.25)\end{array}$ & $\begin{array}{l}0.75 \\
( \pm 0.05)\end{array}$ & $\begin{array}{l}1.27 \\
( \pm 0.22)\end{array}$ & $\begin{array}{l}0.37 \\
( \pm 0.04)\end{array}$ & $\begin{array}{l}0.48 \\
( \pm 0.04)^{*}\end{array}$ & $\begin{array}{l}25.00 \\
( \pm 5.57)\end{array}$ \\
\hline & Coated & $\begin{array}{l}21.25 \\
( \pm 1.5)\end{array}$ & $\begin{array}{l}465.67 \\
( \pm 47.35)\end{array}$ & $\begin{array}{l}1.26 \\
( \pm 0.04)^{*}\end{array}$ & $\begin{array}{l}10.97 \\
( \pm 1.03)\end{array}$ & $\begin{array}{l}75.04 \\
( \pm 3.48)\end{array}$ & $\begin{array}{l}0.17 \\
( \pm 0.02)\end{array}$ & $\begin{array}{l}0.52 \\
( \pm 0.07)\end{array}$ & $\begin{array}{l}0.21 \\
( \pm 0.03)\end{array}$ & $\begin{array}{l}0.47 \\
( \pm 0.03)^{*}\end{array}$ & \\
\hline \multirow[t]{2}{*}{ LDPE } & Uncoated & $\begin{array}{l}47.5 \\
( \pm 1.45)\end{array}$ & $\begin{array}{l}2623.67 \\
( \pm 47.50)\end{array}$ & $\begin{array}{l}1.12 \\
( \pm 0.19)^{*}\end{array}$ & $\begin{array}{l}5.71 \\
( \pm 0.39)\end{array}$ & $\begin{array}{l}84.10 \\
( \pm 0.08)\end{array}$ & $\begin{array}{l}0.64 \\
( \pm 0.06)\end{array}$ & $\begin{array}{l}0.18 \\
( \pm 0.03)\end{array}$ & $\begin{array}{l}0.86 \\
( \pm 0.07)\end{array}$ & $\begin{array}{l}0.46 \\
( \pm 0.08)^{*}\end{array}$ & $\begin{array}{l}25.08 \\
( \pm 1.73)\end{array}$ \\
\hline & Coated & $\begin{array}{l}49.1 \\
( \pm 1.52)\end{array}$ & $\begin{array}{l}1159.67 \\
( \pm 52.60)\end{array}$ & $\begin{array}{l}1.38 \\
( \pm 0.01)^{*}\end{array}$ & $\begin{array}{l}26.13 \\
( \pm 2.40)\end{array}$ & $\begin{array}{l}54.05 \\
( \pm 2.54)\end{array}$ & $\begin{array}{l}0.29 \\
( \pm 0.04)\end{array}$ & $\begin{array}{l}0.20 \\
( \pm 0.04)\end{array}$ & $\begin{array}{l}0.51 \\
( \pm 0.08)\end{array}$ & $\begin{array}{l}0.46 \\
( \pm 0.06)^{*}\end{array}$ & \\
\hline \multirow[t]{2}{*}{ PET } & Uncoated & $\begin{array}{l}12.3 \\
( \pm 0.98)\end{array}$ & $\begin{array}{l}112.33 \\
( \pm 1.53)\end{array}$ & $\begin{array}{l}15.78 \\
( \pm 0.43)\end{array}$ & $\begin{array}{l}3.14 \\
( \pm 0.14)\end{array}$ & $\begin{array}{l}82.27 \\
( \pm 0.32)\end{array}$ & $\begin{array}{l}0.42 \\
( \pm 0.03)\end{array}$ & $\begin{array}{l}0.54 \\
( \pm 0.06)^{*}\end{array}$ & $\begin{array}{l}0.27 \\
( \pm 0.02)\end{array}$ & $\begin{array}{l}0.34 \\
( \pm 0.02)\end{array}$ & $\begin{array}{l}28.33 \\
( \pm 4.16)\end{array}$ \\
\hline & Coated & $\begin{array}{l}13.85 \\
( \pm 1.05)\end{array}$ & $\begin{array}{l}67.10 \\
( \pm 0.70)\end{array}$ & $\begin{array}{l}13.53 \\
( \pm 0.02)\end{array}$ & $\begin{array}{l}10.49 \\
( \pm 0.54)\end{array}$ & $\begin{array}{l}72.69 \\
( \pm 1.02)\end{array}$ & $\begin{array}{l}0.22 \\
( \pm 0.03)\end{array}$ & $\begin{array}{l}0.58 \\
( \pm 0.10)^{*}\end{array}$ & $\begin{array}{l}0.20 \\
( \pm 0.02)\end{array}$ & $\begin{array}{l}0.42 \\
( \pm 0.03)\end{array}$ & \\
\hline
\end{tabular}




\section{Figures Legend}

Figure 1. OM cross-section of polypropylene coated film.

Figure 2. Effect of relative humidity on oxygen transmission rate of uncoated and coated OPP films. Each data point is shown as average of five replicates. Error bar indicates SD.

Figure 3.Effect of relative humidity on oxygen transmission rate of uncoated and coated LDPE films. Each data point is shown as average of five replicates. Error bar indicates SD.

Figure 4. Effect of relative humidity on oxygen transmission rate of uncoated and coated PET films. Each data point is shown as average of five replicates. Error bar indicates SD.

Figure 5. UV light transmittance of uncoated (1) and coated (2) LDPE, uncoated (3) and coated (4) OPP, uncoated (5) and coated (6) PET.

Figure 6. UV light transmittance of uncoated OPP (-), coated OPP (----) and coated OPP without the lipid component in the original formulation (----- ).

Figure 7. Typical curves obtained for static and kinetic friction coefficients determination during the film-to-film test of uncoated and coated OPP. 


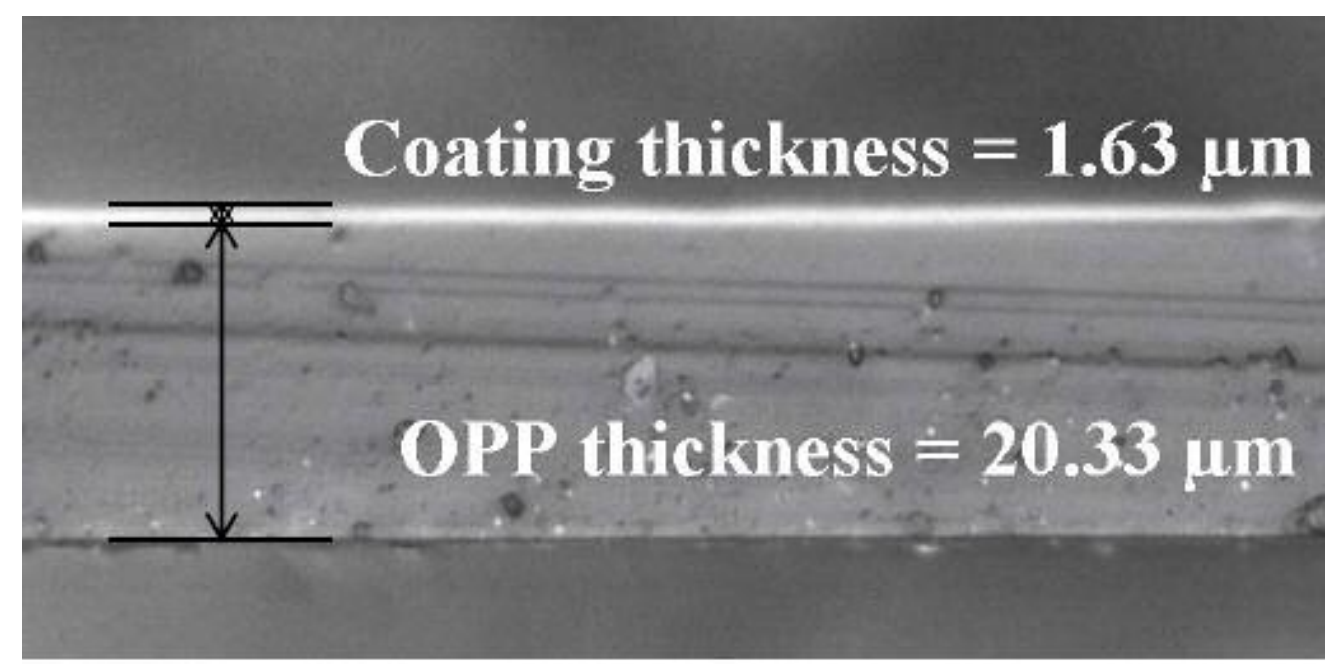

OM cross-section of polypropylene coated film. $135 \times 99 \mathrm{~mm}(96 \times 96 \mathrm{DPI})$ 


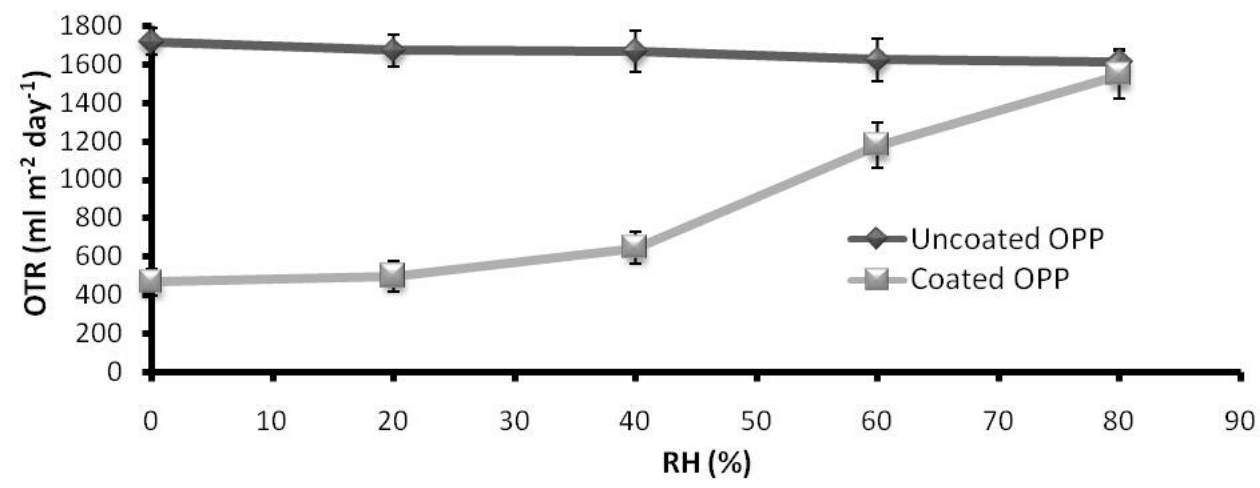

Effect of relative humidity on oxygen transmission rate of uncoated and coated OPP films. Each data point is shown as average of five replicates. Error bar indicates SD. $257 \times 100 \mathrm{~mm}(96 \times 96 \mathrm{DPI})$ 


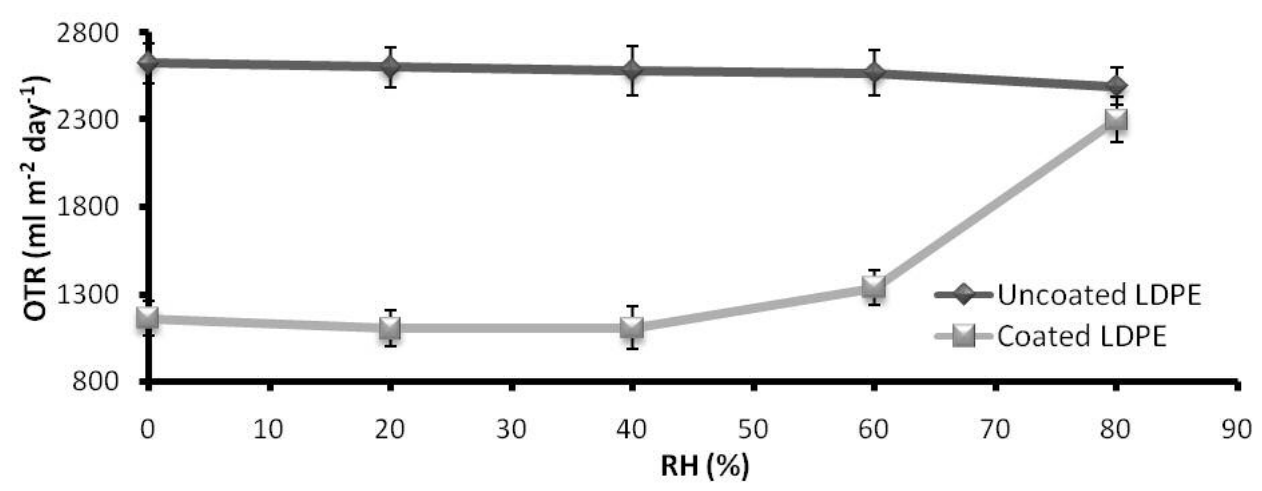

Effect of relative humidity on oxygen transmission rate of uncoated and coated LDPE films. Each data point is shown as average of five replicates. Error bar indicates SD. $257 \times 102 \mathrm{~mm}(96 \times 96 \mathrm{DPI})$ 


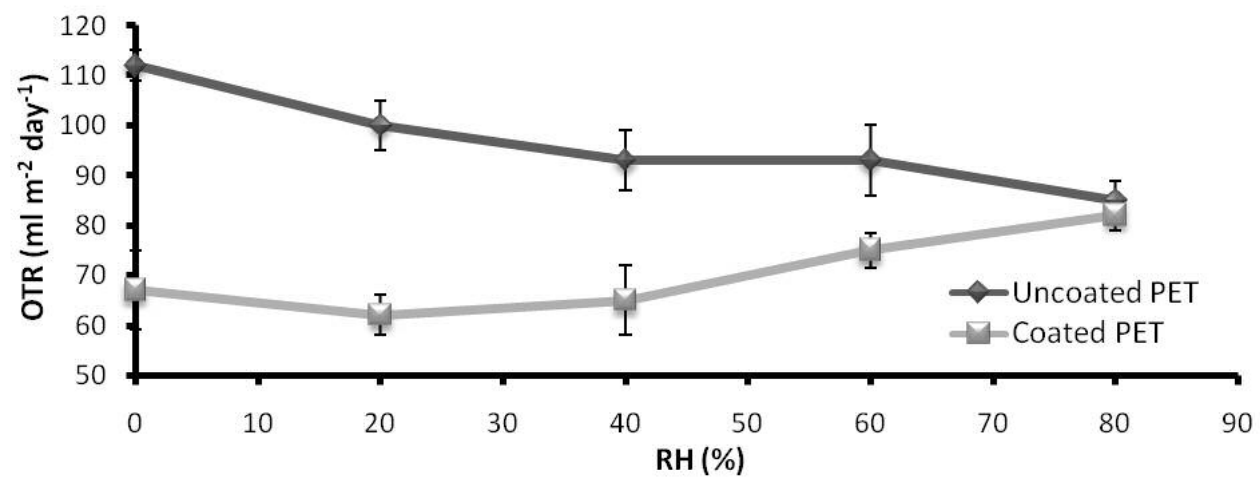

Effect of relative humidity on oxygen transmission rate of uncoated and coated PET films. Each data point is shown as average of five replicates. Error bar indicates SD. $257 \times 104 \mathrm{~mm}$ (96 x 96 DPI) 


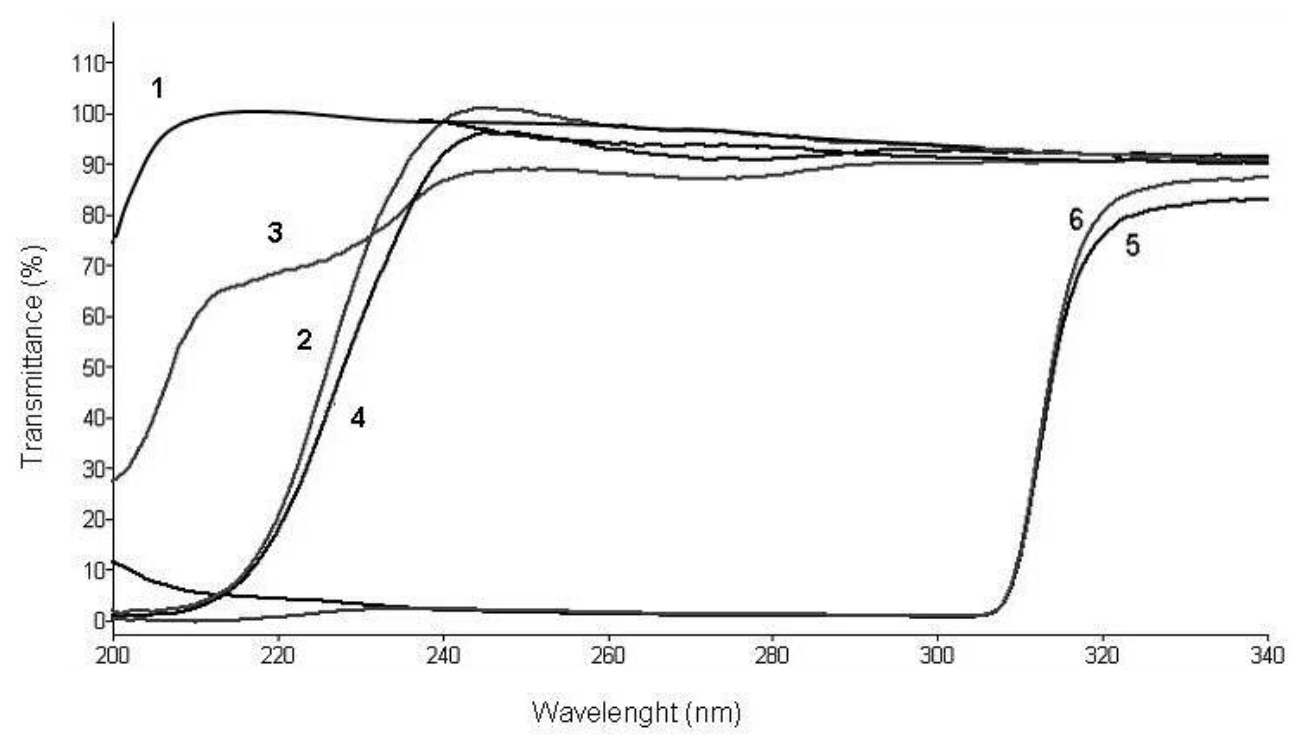

UV light transmittance of uncoated (1) and coated (2) LDPE, uncoated (3) and coated (4) OPP, uncoated (5) and coated (6) PET. $199 \times 135 \mathrm{~mm}$ (96 x 96 DPI) 


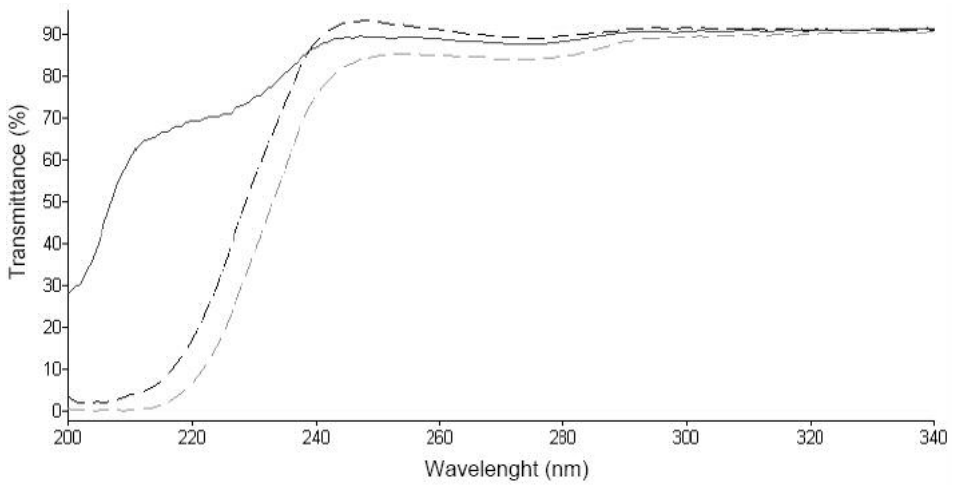

UV light transmittance of uncoated OPP (dashed line), coated OPP (dotted black line) and coated OPP without the lipid component in the original formulation (dotted grey line). $257 \times 104 \mathrm{~mm}(96 \times 96 \mathrm{DPI})$ 


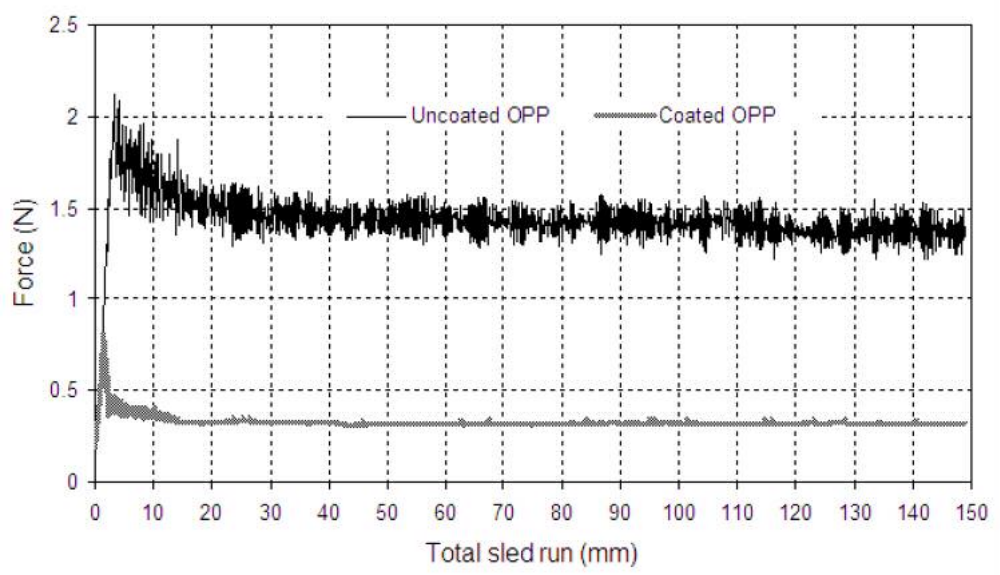

Typical curves obtained for static and kinetic friction coefficients determination during the film-to-film test of uncoated and coated OPP.

$257 \times 115 \mathrm{~mm}$ (96 x 96 DPI) 